\title{
Osmanlıda Yenilikçi Hareketlerle Birlikte Türk Mûsikîsine Eklenen Yeni Türler ve Bu Türlerin Teori-Pratik İkilemi
}

\author{
The New Music Forms added to Turkish Music with Tanzimat and the Theory- \\ Practice Dilemma of These Forms
}

\author{
Seda Tüfekçioğlu \\ Dr. Öğr. Ü., İstanbul Medeniyet Üniversitesi Sanat Tasarım ve Mimarlık Fakültesi Türk Mûsikîsi Bölümü, \\ seda.tufekcioglu@medeniyet.edu.tr
}

\section{Öz}

Osmanlıda yenilikçi hareketlerin başlangıcı olarak Tanzimat'ın ilanı kabul edilir. Sözlükte "düzenlemek, sıraya koymak, 1slah etmek" anlamındaki tanzîm kelimesinin çoğulu olan "tanzîmât", "mülkî idareyi ıslah ve yeniden organize etme" anlamında kullanılır. Mülki idarenin yanı sıra pek çok alanda yeniliklerin yapıldığı bilinmektedir. Sultan Abdülmecid Hân'ın (1839-1861) yayımladığı mülkî 1slahat programı ve uygulandığ yenilikçi hareketlerin başlangıcını Tanzimat olarak sınırlandırmak çok gerçekçi değildir. Özellikle sanat ve sanatın kollarından biri olan mûsikî için yenilikçi hareketler, Sultan III. Selim Hân (1789-1807) ve Sultan II. Mahmut Hân (1808-1839) dönemine kadar indirilebilir. Bu yenilikçi hareket kullanılan makamlar, usuller, repertuar, nazariyat, müzik yazısı, formlar gibi pek çok alanda göze çarpmaktadır. Günümüzde kullanılan mûsikî formlarının tarifi, eserler incelendikten sonra elde edilen veriler ile klasik kurallar birleştirilerek yapılmıştır. Aslında Türk mûsikîsinin kurallar üstüne icra edilen bir tür olmadığı, kuralların bu mûsikî üzerine yazılmış olduğunu söylemek daha doğru olacaktır. Bu araştırmada özellikle yenilikçi hareketlerin başlamasıyla Türk mûsikîsinde kullanılan yeni mûsikî formlarının karşılaştırılmalı olarak ortaya konmasının yanı sıra daha önceki dönemlerde kullanılmış formların teori-pratik ikilemi içerisinde kuralların ne derece eserlerle örtüştüğü değerlendirilmiştir.

Anahtar Kelimeler: Yenilikçi Hareket, Tanzimat, Mûsikî, Türk Mûsikîsi Formları

\begin{abstract}
Tanzimat, the plural of word tanzim, has been used in the meaning of "regulate, put in order, reform and re-organize civil administration". Civil reform program and the implemented period which issued by Sultan Abdülmecid Hân (1839-1861) is called as "Tanzimat Period". It is known that innovation made in civil administration as well as made in many areas. However, to limit the beginning of this reformist movement from Tanzimat period is not very realistic. This reformist movement can reduce the period of Sultan III. Selim Hân (1789-1807) and Sultan II. Mahmut Hân (1808-1839) especially for music which is one of the section of art. This reformist movement is an outstanding act in many areas such as maqam-mode (makam), tempo-rhythm (usul), repertoire, theory, music writing, and music forms. Turkish music forms have been described after combining classical rules with the data obtained after examining the works. In fact, it would be more accurate to say that Turkish music is not a form performed that is applied on the rules but the rules applied on this music. In this study, by putting forward used new Turkish music forms and the rules explained on these types to what extent overlap
\end{abstract}


with the work especially with the start of innovative movement will be evaluated within the theorypractice dilemma. Also, some New Turkish music form samples will be played during the presentation.

Keywords: Reformist Movement, Reorganizations, Music, Turkish Music Forms

\section{Giriș}

Türk mûsikîsinde zaman ile ortaya çıkan değişim, Türk mûsikîsi formlarında da yaşanmıştır. $\mathrm{Bu}$ değişimin başlangıcı III. Selim'e kadar uzatılabilir. Daha sonrasında Tanzimat ile birlikte değişim süreci hızlanmıştır. Tanzimat, kelime manası olarak “düzenlemek, sıraya koymak, 1slah etmek” anlamına gelen tanzim kavramının çoğuludur. 3 Kasım 1839'da Gülhane Hatt-1 Hümâyunu ile başlayan dönem mülkî idareyi ıslah ve yeniden organize etme olarak literatürde yerini almıştır (Akyıldız, 2011, s. 1).

Sultan III. Selim Hân ile başlayan Tanzîmât'la devam eden fakat daha çok Islahât Fermanı'ndan sonra kendini göstermeye başlayan reformlar Abdülmecid'le devam eden yenilikçi politikalar Sultân Abdülaziz zamanında da devam etmiş ve çok geçmeden mûsikîyi de etkilemeye başlamıştır. Sultan II. Mahmud Hân döneminde Yeniçeri Ocağının kaldırılmasının ardından yine bu dönemde Mehter kapatılarak yerine Muzika-i Hümayun kurulur. Muzika-i Hümayun ile Türk müziğinde yeni arayışlara, yeni açılımlara yönelme çalışmalarına başlanmıştır. Böylelikle Sultan III. Selim Hân döneminde "geleneksel" boyutta başlayan modernleşme süreci II. Mahmud ile devam ederek Osmanlı Devleti'nin kendini Avrupa'ya karşı güncellemesi ile müzik yaşamında da bir değişim söz konusu olmuştur (Aksoy, 1985, s. 1212; Özden, 2019, s. 8). Bu yenilikçi hareket kullanılan makamlar, usuller, repertuvar, nazariyat, müzik yazısı yanı sıra mûsikî formlarını da etkilemiştir.

Form kelime anlamıyla "eser biçimi" olarak ifade edilebilir. Her müzik türünde olduğu gibi Türk mûsikîsinde de farklı formlar kullanılmıştır. Edebiyatta gazel, destan, şiir gibi birçok biçim olduğu gibi mûsikîde de farklı biçimler görmek mümkündür. Makam sistemine dayalı Türk mûsikîsinde, aynı makamdan bestelenmiş pek çok eser bulunur. Ancak bu eserlerin her biri ayrı bir ifade tarzına sahiptir. Her eserin kendine özgü bir üslubu vardır ve belli kurallar dairesinde yeni hüviyetler kazanır. Bazıları uzun, bazıları kısa, bazıları usul yönünden farklılıklar arz eder (Özkan, 1984, s. 79).

\section{Türk Mûsikîsi Formlarının Tarihsel Süreci}

Türk mûsikîsinde yüzyıllar boyunca pek çok farklı form kullanılmıştır. İslamiyet öncesi Türklerde mûsikî şiir ile birlikte düşünülmüş ve kopuz eşliğinde şiirler okunmuştur. "Sığır" denilen sürgün av âyinlerinde, "şeylan" veya "toy" denilen ziyafet âyinlerinde ve "yuğ" denilen matem âyinlerinde yine kopuzla şiirler okumuşlardır. Türklerin icra ettikleri bu mûsikî türü ise ikiye ayrılmıştır. Mûsikî aleti kullandıkları ezgiler "gök" veya "kök"; sesli olarak icra edilen ezgiler ise "ir" veya "dule" olarak adlandırılmıştır (Özcan, 2001, s. 17).

Arap mûsikîsine baktığımızda özellikle Hz. Osman dönemine kadar "nasb", "hudâ" ve "inşâd" denen bazı basit mûsikî formlarının kullanıldığını görebilmekteyiz. "Nasb", deve sürücülerinin veya kadınların kullandıkları bir formdur. "Hudâ" ise "nasb" ile aynı mânâda kullanılmakla beraber, işlediği konu açısından farklılıklar gösterebilen bir formdur. Hudâ Arap ğınâsının ilk örneğidir. İnşad ise şiiri arûz yapısına uygun bir şekilde yüksek ve ahenkli bir sesle okumaktır. Araplar'ın inşâd esnasında def gibi ritim aletleri kullandıkları da belirtilmektedir. Çoğunlukla "şarkı"nın karşı1lığı olarak, zaman zaman da "mûsikî" için "el-ğınâ" ve "el-tenab" kullanılmıştır (Turabi, 1996, s. 3-4).

XI. yüzyılda Kaşgarlı Mahmud'un Araplara Türkçeyi öğretmek maksatlı yazılmış Dîvân ü Lügât 'it Türk adlı eserinde mûsikî ile alakalı kelimeler de azımsanmayacak kadar çoktur. Akdoğu bu terimleri bir 
makalelerini topladığı kitabında listelemiştir. Şarkı, mûsikî veya icra edilen ezgilerin karşılığı olarak “ır” veya "yır” kullanılmıştır. Bu kelime "gazel”in karş1lığı olarak da söylenmiştir (Akdoğu, 2005, s. $35)$.

İslâmiyet'in kabulünden sonra IX. yüzyıl itibariyle mûsikî nazariyatı konusunda yapılmış olan sistematik çalışmalar, daha sonra yazılacak olan edvâr kitaplarına da ilham kaynağı olmuştur. XIII. yüzyıl başında edvâr geleneğini başlatan Safiyyüddîn el-Urmevî mûsikî nazariyatı alanında önemli eserler te'lif etmiştir. Daha sonraki yüzyıllarda üzerine birçok şerh yazılacak olan Kitâbü'l-Edvâr adlı eserinin son bölümünde "tarîka" ve "savt" adlı iki form adını zikreder. "Tarîka", fasıl başında icra edilen XVI. yüzyıldan önce peşrev formu hükmünde, bir nevi giriş müziği olarak eserlerin başında icra edilmiştir. "Savt" ise Arapça teganni anlamına gelen meyansız ve terennümsüz basit bir sözlü beste formuna verilen addır (Uygun, 1999, s. 127-128-240-241).

XV. yüzyıla bakıldığında özellikle bu asırda yazılmış olan edvâr kitaplarında mûsikî formlarının ele alındığı görülür. Yazmış olduğu mûsikî nazariyatı eserleri ile daha sonradan pek çok mûsikişsinasa yol gösterici olacak dönemin ünlü mûsikîşinası Abdülkadir Merâğî de "neşid-i arab", "basit", nevbet-i müretteb", "küllü’d-durûb", "küllü’n-nağam" "darbeyn", "amel”, "nakş", "savt", "hevâyi”, "pişrev", "zahme" ve "murassa" olmak üzere on dört farklı mûsikî türünden söz etmiştir (Bardakçı, 1986, s. 9194).

Özellikle XV. yüzyılda sıkça tercih edilen "nevbet-i müretteb" formu ise birbirini takip eden "kavl", "gazel”, "terane" ve "furudaşt” denilen dört formdan müteşekkildir. Dönemin en geniş mûsikî formudur. Nevbet-i mürettebin en önemli özelliği, muntazam bir sıra ile dizilmiş bölümler arasında makam-usul birliğiyle eserin icra edilmesidir (Agayeva, 2007, s. 41). Yine aynı yüzyılda Merâği'nin oğlu Abdülaziz B. Merâği Nekavetü'l Edvar adlı eserinde usullü ve usulsüz olmak üzere "nevbet-i müretteb", "basit", "küllü’d-durûb, "darbeyn", "küllü’n-nağam”, “amel”, "nakş", "savt”, "pişrev", “zahme”, "kıta”" adlı türlerden söz eder (Koç, 2010, s. 76).

XVI. yüzyıl önemli mûsikîşinaslarından biri olan Ali Ufkî Bey'in yazmış olduğu Hâzâ Mecmu'a-i Saz $\ddot{u}$ Söz adlı eser XVI. yüzyılın en kıymetli eserlerinden biridir. Tercüman ve müzisyen olarak sarayda görev yapan Ali Ufkî Bey'in bu eseri pek çok notayı içermektedir. Bu eserde aynı zamanda "ilahi", "kâr", "murabba", "nakş", "raks ve raksiyye", "sözel semai", "şark1", "tekerleme", "tesbih", "varsağı" ve "beste" formları yer almaktadır (Cevher, 1995, s. 50-52).

XVIII. yüzyılda ise özellikle Kantemiroğlu'nun (Dimitrius Cantemir) Kantemiroğlu Edvârı diye anılan Kitâbu İlmi'l-Mûsikî alâ Vechi'l-Hurûfât adlı eserinde "Fasl-1 İcrâ-1 Mûsikî" başlığı altında mûsikînin iki türlü olduğunu belirtmiştir: "Biri nefesten ve biri sazdan. Nefesten olana hânendelik, sazdan olana sâzendelik denir. Mûsikî formları da beş türlüdür: taksim, beste, nakş, kâr, semâî” (Kantemiroğlu'ndan aktaran Tura, 2001, s. 173).

\subsection{Klasik Fasıllardan, Günümüz Fasıllarına Değişim}

Fasıl Arapça "bölüm, kısım, ayırım, devre" anlamına gelmektedir. Belli bir makama ait eserler topluluğunun form bakımından büyükten küçüğe ve usul bakımından ağırdan yürüğe doğru sıralanmış eserlerin icra edilmesidir (Özkan, 1995, s. 207).

Fasıl terimi ilk XVII. yüzyılda güfte mecmuaları ve nota mecmualarında görülmektedir. XVIII. yüzyılda Kantemiroğlu Kitâbü IIlmi 'l-mûsikì ala vechi'l-hurufât adlı eserinde faslı sâzende faslı, hânende faslı, sâzende ve hânende müşterek faslı olmak üzere üçe ayırmaktadır. Buna göre sâzende faslında önce taksim ile başlanır. Daha sonra peşrev ve saz semaisi icra edilmektedir. Hânende faslında ise önce gazel ile başlanır. Daha sonra beste, nakış, kâr okunur ve semai formu ile biter. Sâzende ve hânendelerle yapılan müşterek fasılda önce bir sazla taksim yapılır, ardından bir veya iki peşrev çalınır, bunu takiben 
bir gazel okunduktan sonra beste, nakış, kâr ve bir semâi okunup bir saz semaisi çalınır, tekrar bir gazel okunarak fasla son verilir (Kantemiroğlu'ndan aktaran Tura, 2001, s. 187).

XIX. yüzyıla kadar icra edilen fasıllar "klasik fasıl” olarak adlandırılmıştır. Eserler klasik devrin özelliklerini yansitan büyük formlardan müteşekkil ciddi, sanatlı eserlerdir. Klasik fasıl taksimin ardından peşrev ile başlar daha sonrasında sözlü eserlere geçilerek sirasıyla kâr, birinci beste, ikinci beste, ă̆ır semai, yürük semai okunur ve en son saz semaisi, sirto veya longa gibi bir saz eseri ile biter. Zaman zaman bazı türler atlanarak eser sıralamasında bazı küçük değişiklikler yapılabilir. Meselâ kârın icra edileceği fasıllarda tek beste okunabilir. Tanzimat öncesi fasıllarda şarkı formu fazlaca kullanılmamış daha ziyade kâr, beste, semâi formları tercih edilmiştir. XIX. yüzyıldan itibaren Hacı Ârif Bey (1831-1885) ile birlikte şarkı formu ön plana çıkmış ve fasıllarda da bu form sıklıkla yerini almaya başlamıştır. Hatta bu şarkıların birbirilerine bağlanması amacıyla ara nağmeler bestelenmiştir. Fasıl eğlence müziğine meyletmekle beraber her şeye rağmen beste, semai gibi formlar icradaki varlıklarını korumaktaydılar. 1960'lardan sonra fasıl eğlence müziğine gitgide meylederek fasıl da olumsuz yönde etkilenmiştir (Özkan, 1995, s. 207-208).

Günümüzde ise kâr, beste, semâi gibi büyük formlar terk edilmiş olup sadece usulleri ağırdan yürüğe doğru şarkıların ara nağmelerle birbirine bağlanması ile oluşturulan fasıllar icra edilmektedir. Bu icrada faslın ortasında bir saz tarafından taksim yapılmakta ve gazel okunmakta sonunda da saz semaisi, longa, sirto veya bir oyun havası çalınarak fasıl sona ermektedir. Bu fasılların klasik fasılla bir ilgisi yoktur. Klasik fasıl ile birebir örtüşmese de fasıl ciddiyetini korumaya çalışarak, fasıl icra etmeye devam eden bazı günümüz mûsikîşinaslarından serhânende Nurettin Çelik veya Mehmet Güntekin gibi isimlerini de ayrıca zikretmek gerekir.

\subsection{Sözlü Mûsikî Formlarında Değişim}

Günümüzde kullanılan Türk din mûsikîsi dışında kalan sözlü mûsikî formlarını büyük formlar ve küçük formlar olarak ikiye ayırmak mümkündür. Büyük formda olanları kâr, kâr-ı nâtık, kârçe, beste (murabba ve nakş şekli), semâiler a- ağır semâî (murabba ve nakş şekli) b- yürük semâî (murabba ve nakş şekli) olarak sınıflandırabiliriz. Tanzimat öncesi klasik fasıl olarak nitelendirilen fasıllarda da bu sıra takip edilmiştir.

Klasik fasıl sırlamasında ilk okunan sözlü eser türü "kâr"dır. Peşrevden sonra, birinci besteden önce icra edilir. Sözlü Farsça'da "iş" anlamına gelen "kâr” formu uzun soluklu güfteye dâhil olmayan lafzî ve ikaî terennüm ile başlamaktadır. Türk mûsikîsi sözlü formları içinde en uzun ve en sanatlı olan şeklidir (Özkan, 2001, s. 356). Mûsikîde "kâr" formunu ayıran en önemli özellik "terennüm" dediğimiz güfteye dâhil olmayan kısımla başlamış olmasıdır. Ancak istisnâ olarak Buhurizâde Mustafa Itrî tarafindan bestelenmiş olan Neva Kâr' 'n terennümle başlamadığı görülür. Güfteleri dörtlü, altıll, sekizli vs. olabilir. Belli bir simetri veya yapı aranmaz. Bundan dolayıdır ki kâr bestekârları geniş bir serbesti içinde makam ve usul geçkileri yaparlar (Yavaşça, 2002, s. 403).

Özellikle XV. yüzyılda Meraği'nin bahsettiği formlar arasında yer alan "amel" formu ise bazı kaynaklarda daha sonradan kâr adını aldığı ileri sürülmüştür. Amel İranlılar tarafindan kullanılan Farsça bestelenmiş eserlere verilen addır. Yapısı bakımından incelendiğinde birinci kısım "matla", ikinci kısım “cedvel”, üçüncü kısım "savtü'l-vasat (meyan)" ve dördüncü kısım "teşyi”" olarak adlandırılır. Bu form bugün de "murabba beste" formu olarak kullanılmaya devam etmektedir (Tura, 1985, s. 61-62). Görüldüğü gibi aslında amel formu Farsça sözleri olması dışında yapısal olarak bakıldığında kâr formu özelliklerinin değil; bir mısra bir terennüm şeklinde icra edilen dört mısralı murabba beste formunun özelliklerini taşımaktadır. 
"Şarkı” formu klasik üslubun son dönemine doğru halk edebiyatının murabba nazım şekli olan türkü ve koşma türlerinin etkisi altında XVII. yüzyılda ortaya çıkmıştır. XVIII. yüzyılda özellikle Hacı Ârif Bey (1885) ve Şevki Bey (1890) ile önem kazanmış ve gelişmiştir (Özkan, 2010, s. 358). XIX. yüzyılın ikinci yarısından itibaren özellikle büyük formlar içinde terennüm kullanma zorunluluğu şarkı formu ile ortadan kalkmıştır. Özellikle Hacı Arif Bey şarkı formunu evrimleştirerek daha önce büyük formların sanatlı ancak kısıtlı çerçevesi içinde dört musiki cümlesi içinde kalmayarak daha fazla mısralı, usul geçkili eserler ortaya koyarak terennüm kullanmadan büyük formların imkânlarını şarkıya kazandırmıştır (Aksoy, 1985, s. 1231). Özellikle XVIII. yüzyılda Lale Devri ile başlayan, daha sonrasında XIX. yüzyılda Tanzimat'la ve Cumhuriyet'le birlikte geniş kitlelere yayılan şarkı formu hem beste hem de güfte anlamında popülerleşme eğilimine girmiştir. Şarkılarda popülerleşmeyi kolaylaştıran bir unsur heceye düşen nota sayısının gitgide azalması ve de küçük usullerin tercih edilmiş olmasıdır (Alimdar, 2016, s. 478-479-482). Bugün ise özellikle tüm bestelenmiş eserlere genel mânâda şark1 adı verilmektedir. Popüler kültürle birlikte şarkı terimi form özelliğini kaybetmiş, anlam kaymasına uğramış, tüm müzik eserlerine şark1 adı verilmiştir. İngilizce'de "song", Almanca'da "lied" ve Fransızca' da "chanson" terimlerinin karşılığı olarak şarkı terimi kullanmıştır (Tohumcu, 2007, s. 711).

\subsection{Saz Mûsikîsi Formlarında Değişim}

Dünyadaki tüm müzikler din kaynaklıdır ve Hz. Adem'den beri musiki ve din iç içedir. Cami, kilise, sinagog gibi mekânlar müziğin icra edilmesi noktasında önemli mekânlardır. İslam dünyasında ibadet yeri olarak kullanılan camilerde insan sesinden başka herhangi bir enstrüman yer almaz. İnsan sesi en mükemmel müzik âleti olarak kabul edilmiştir. Tüm sazların icat edilme amacı insan sesini taklit etmek ve ona refakat etmek olduğu söylenebilir. Bundan dolayıdır ki saz musikisi çok uzunca bir dönem ikinci planda yer almıştır. Batı müziğinde ise bu durum tam tersidir (Öztuna, 1969, s. 212).

XIX. yüzyıl itibariyle yenilikçi hareketlerle birlikte mûsikîde ki yenilikler saz eserlerinde de görülmeye başlamıştır. Sadece saz eseri besteleyen sanatçıların ortaya çıkması bu dönemden sonra artmıştır. $\mathrm{Bu}$ yolda en önemli örneklerden biri hiç şüphesiz Tanburî Cemil Bey'dir. Sadece bestecilik anlamında değil icra ettiği sazlar ile yorumculuk anlamında da saz mûsikîsine yeni bir hüviyet kazandırmıştır. Aynı zamanda yaptığı taksimler birer beste değeri taşımaktadır (Aksoy, 1985, s. 1231).

Saz mûsikîsi içinde en çok bilinen türlerden biri hiç şüphesiz "peşrev" formudur. Peşrev Farsça "pişrev" önde giden anlamını taşır. Günümüze ulaşan en eski peşrev örnekleri Sultan II. Bayezid Hân'a ait üç peşrevdir (Yavaşça, 2002, s. 45). XVIII. yüzyılda yaşamış ve hayatının bir kısmında İstanbul'da bulunmuş olan Charles Fanton'un özellikle o döneme ait Türk mûsikîsi için pratik ve somut bilgiler bulunan Deneme adlı eserinde peşrevin çoğu kez dört bölümden meydana geldiğini belirtir. İlkine "serhâne", ikincisine "mülâzime", üçüncüsüne "miyan-hâne", dördüncüsüne de "son-hane" adı verilir. Dört bölümün ardından İtalyan sanatlarında da "çabuk, hızlı" anlamına gelen presto bölümüne benzer, semai adında bizzat eserin bölümü gibi olmayan bir parça gelir. Daha canlı ve hızlı ritimde icra edilir. Bu bölümün amacının dinleyiciyi diğer bölümlerdeki büyüleyici havadan uzaklaştırmak olduğunu da ekler. (Fonton, 1987, s. 72) Fonton burada her ne kadar peşrev tarifi yaparken son bölümünün semai olduğunu belirtmiş olsa da peşrev formunun özelliklerine bakıldığında peşrevin son hanesinde semai bölümü yer almaz. Burada bahsedilen Kantemiroğlu'nun tanımladığı sazende faslının son bölümü olarak icra edilen saz semaisi'dir. Semai kısmı ise başlı başına ayrı bir form olarak icra edilmektedir (Aksoy, 1994, s. 109).

Saz mûsikîsi türleri içinde peşrevlerden sonra ikinci önemli ve sık kullanılan tür "saz semaileri"dir. Özellikle fasıl sonlarında icra edilmek üzere bestelenmiş ritmik eserlerdir. Genellikle dört hane şeklinde bestelenmiş, ilk üç hane aksak semai usulünde ölçülürken dördüncü hanede usul değişikliği yapılarak semai, yürük semai, curcuna gibi usullere geçilmektedir. (Yavaşça, 2002, s. 64). Gelenekte saz semaileri 
birinci, ikinci ve üçüncü hane ve mülazime iki kez çalınır, dördüncü hane de iki kez çalındıktan sonra son çalınan mülazime tek icra edilirdi. Plak kayıtlarına bakıldığında meyan hâne olarak bilinen üçüncü hanenin ilk çalınışı tizden ikinci tekrarı pest perdeden çalındığı görülür (Özalp, 1992, s. 7).

Yenilikçi hareketlerle birlikte XX. yüzyıl başlarında saz semaisi formunun da değişime uğradığını söyleyebiliriz. Meselâ; Tanburî Cemil Bey, Udî Arşak Çömlekçiyan, Sedat Öztoprak, Refik Talât Alpman gibi saz semaisi bestekârlarının eserleri incelendiğinde Batı müziğinin etkisi hissedilmekte, arpej ve üçlemelerin birlikte kullanıldığı görülmektedir. Ayrıca kromatik seslerin yine bu yüzyıl itibariyle saz eserlerinde yer aldığı dikkat çekmektedir. Bunu yanı sıra ajilite (çabukluk-çeviklik) icra teknikleri eserlere dâhil edilmiş, hızlı pasajlar, otuz ikilik notalar yine saz semailerinde yerini almıştır (Alimdar, 2016, s. 512-515). Daha sonraki dönemlerde XX. yüzyıl sonu XXI. yüzyıl başında Mesut Cemil, Reşat Aysu, Cinuçen Tanrıkorur gibi bestekârların eserleri de sâzende icrasını zorlayacak seviyede eserler ortaya çıkarmışlardır. Günümüzde ise her sazın kendi tekniğine uygun bestelerin yapılması ayrıca dikkat çekicidir. Mutlu Torun, Göksel Baktagir, Yurdal Tokcan bu bestekârlardan bazılarıdır.

XIX. yüzyıl itibariyle yeni saz mûsikîsi türlerinin de ortaya çıktığı görülmektedir. Buna bir örnek "medhal” formudur. XIX. yüzyıl mûsikî muallimi, bestekâr ve ud icracısı Ali Rıfat Çağatay tarafından ilk defa kullanılmıştır. Peşrev formuna benzer bir yapıda ancak daha küçük usullerle ölçülmüş kısa peşrev olduğu söylenebilir (Yavaşça, 2002, s. 76). Zaman zaman bazı peşrevlerin bir bölümünün de medhal olarak icra edilmektedir. Bunun için mûsikî icracıları tarafından en bilinen örnek Refik Fersan'ın Musâhabât-ı Mûsikîye adlı eseridir. Eser dört hane bir teslim şeklinde peşrev formu yapısında bestelenmiş olmasına rağmen ilk hanesi ve teslim bölümü Rast medhal olarak icra edilmektedir.

Bunun dışında yeni eklenen türlere diğer iki örnek "sirto" ve "longa"lardır. Sirto Yunanca geleneksel, şenlikli anlamına gelen ve kökeni MS. I. yüzyıla dayanan kadın ve erkeğin birbirinin omzuna ellerini atarak halka şeklinde beraber oynadıkları bir tür halk oyunudur (Aktüze, 2003, s. 528). Ancak Türk mûsikîsinde kullanılan sirtolar oyun havası sayıldığı halde raks unsuru olarak icra edilmemiştir. Longa ise Romen kökenlidir. Sirtolar gibi longalar da raks amaçlı bestelerdir. Ancak yine Türk mûsikîsinde kullanım şeklinde raks unsuru olarak icra edilmez. Sirto ve longa birbirine benzer iki formdur. Her iki form da Türk mûsikîsine XIX. yüzyıl itibariyle girmiştir. Longalar daha hızlı karakterli olmasına rağmen zaman zaman hızlı karakterli sirtolara da rastlanmaktadır. Her iki form da özellikle Türk mûsikîsinde fasıl sonlarında da icra edilmektedir. Santurî Ethem Bey en çok longa besteleyen bestekârımızdır. (Yavaşça, 2002, s. 97). Benzerlikleri dolayısıyla zaman zaman bu iki formun birbiriyle aynı adla kullanıldıkları da görülmüştür. Longaların günümüz icralarında genellikle eserin bütünü çalındıktan sonra arada bir taksim yapılıp sonrasında tekrar eser daha hızlı bir şekilde icra edilip eser tamamlanmaktadır.

"Mazurka" ve "polka" formu da Tanzimat sonrası saz mûsikîmize giren iki tür olarak karşımıza çıkmaktadır. Bu iki türde az sayıda eser bestelenmiştir. Mazurka XVII. yüzyılda Polonya'nın Mazurya bölgesinde $3 / 4^{\prime}$ lük veye $3 / 8^{\prime}$ lik ölçüde orta hızda dans unsuru olarak bestelenmiş türe verilen addır (Aktüze, 2003, s. 342). Mazurkalar genel bir temel adım ve pozisyonlara ait çeşitlendirmeye ait dört veya daha fazla çiftin karşılıklı dansıdır. İlk olarak bir dans ve daha sonra müzik için bir kaynak olarak, XVIII. ve XIX. yüzyıllarda Avrupa'ya yayılmıştır. Daha sonra Chopin'in piyano mazurkaları literatüre hâkim olmuştur (Apel, 1981, s. 512). Türk mûsikîsi içinde çok fazla rastlanmayan bu tür özellikle XX. yüzyılda Haydar Tatlıyay tarafından tercih edilmiştir. Noktalı bir sekizlikten sonra onaltılık notanın geldiği ritim ile meydana gelmiştir (Yavaşça, 2002, s. 105). "Polka" ise iki vuruşlu Çek halk müziğine verilen addır. Dans hocaları üç vuruşlu mazurka ile polkayı birleştirerek Polka-Mazurka adlı yeni bir halk oyunu türünü de ortaya çıkarmışlardır (Aktüze, 2003, s. 436). 1830'da Bohemya'da doğmuş ve 
kısa sürede Avrupa salonlarına yayılmıştır. Besteci Dvorak tarafından müziğe aktarılmıştır. (Apel, 1981:685). Polka, Türk mûsikîsinde en çok Santurî Ethem Bey tarafından tercih edilmiştir (Yavaşça, 2002, s. 105).

Ayrıca "tasviri" olarak nitelenen belli bir kural dâhilinde yer almayan tasviri eserler yine mûsikîmizde yenilikçi hareketlerle birlikte kullanılmıştır. Batı müziğine baktığımızda ilk tasviri eserlerin XIV. yüzyıldan itibaren ortaya çıktığı görülmektedir. Avlanma ve gündelik hayatta bağrışmaların tasvir edildiği “caccia”lar şiirsel bir müzik türü olarak karşımıza çıkmaktadır. XVI. yüzyılda Clement Jannequin'in bazı eserleri hayvan sesleri ve savaş gürültülerini tasvir eder. Türk mûsikîsinde tasviri eser olarak niteleyebileceğimiz eserler XX. yüzyıl başlarına rastlamaktadır. Ondan öncesinde beste adlarında daha çok tasviri adlar kullanılmıştır. Gülistan (Gül Bahçesi) Pençgâh Peşrev, Nayi Şeyh Osman Efendi'nin Naz ü Niyaz (Naz ve Yakarma) Sabâ Peşrevi, Sultan I. Mahmud Hân'ın Feth-i Bağdad adlı Bûselik Peşrevi örnek verilebilir (Alimdar, 2016, s. 504).

Belli bir ritim unsuruna bağlı kalmadan, herhangi bir beste formuna uymayan bazen tek, bazen değişmeli usullerin kullanıldığ 1 , bir makam çerçevesinde son 40-50 yıldır bestelenmiş "saz eseri" olarak adlandırılan türlerin de tasviri şekilleri olduğu görülmektedir. Adı ile müsemma tasviri eserler sınıflandırmasında düşünebileceğimiz eserler de yine XX. yüzyıl itibariyle bestelenmiştir. Mesela; Şerif Muhiddin Targan'ın Koşan Çocuk adlı eseri, Göksel Baktagir'in Dalgalar, Flamenco Turca, Merdiven, Martı gibi eserleri örnek verilebilir.

Bunun dışında Tanburî Cemil Bey'in doğadaki sesleri taklit ettiği "tasviri taksim”leri birer beste ve belge niteliğindedir. Meselâ; Çoban adlı klasik kemençe ile yaptığı taksiminde köpek havlaması, kurt seslerini tasvir ederken, Ninni adlı yaylı tanbur ile yaptığı taksiminde bir annenin bebeğine söylediği ninniyi ve iki komşu arasındaki konuşmayı tasvir etmektedir (Tanburî Cemil Bey Külliyatı, 2016: disk 5, parça 11; disk 4, parça 11).

Yavaşça "taksim"in improvize yani doğaçlama icra tarzı olduğunu ve de sanatçının makamlar arasında ustalıklı olarak taksimat yapmasından doğan sanat gösterisi olduğunu söylemiştir. Sesle yapılan irticali gazeller de aynı şekilde icra edilir (Yavaşça, 2002, s. 105).

Kantemiroğlu taksim tanımını şu şekilde yapmıştır: "Taksim okunacak bestenin makamında fakat usule bağll olmayan, güzel ve hoş nağmedir ve her şeyden önce icra edilir. Bütün Nağmeleri Bir Araya Toplayan Taksim 'in Tarifi sırasında etraflıca açıklanmıştır" (Kantemiroğlu'ndan aktaran Tura, 2001, s. 173). Kantemiroğlu'nun burada tarif ettiği taksimde bütün nağmelerin bir araya toplandığı taksim "taksim-i küll-i külliyat" yani o dönemde kullanılan tüm makamların bulunduğu taksimlerdi. Bu da tabii olarak uzunca bir süreyi, sâzendenin üstün yeteneğini ve geniş bilgisini gerektiriyordu (Aksoy, 1994, s. 109). Özellikle XIX. yüzyıl itibariyle yapılan taksimlerin süresinin de kısaldığı görülmektedir. Bunda kayıt teknolojisinin gelişmesinin rolü vardır. Plaklarda kâr, beste gibi büyük formdaki eserlerden çeşitli şarkılara, türkülere ve taksimlere kadar değişik formlarda eserler yer almıştır. XIX. yüzyıl başında Osmanlının fonograf ve daha sonraları fonografin geliştirilmiş şekli olan gramofon ile tanışması ile ses kayıtlarının yaygınlaşması ve müziği olan etkileri görülmeye başlamıştır. 1923 yılında kurulan Odeon Plak şirketi de 1925 yılında Türkiye'de ilk defa taş plak kaydı gerçekleştirmiştir (Paçacı, 2010, s. 314). Taksimin en eski örneklerine XX. yüzyıl başında 78 devirli plaklara doldurulan plaklardan dinleyebiliyoruz. $\mathrm{Bu}$ taksimler özellikle üç dört dakikaya sığdırılan taksimlerdir. Aynı şekilde konserlerde icra edilen taksimlerin de süreleri kısalmıştır (Aksoy, 1994, s. 109).

\section{Mûsikîde Yer Alan Terimler ve Teori-Pratik İkilemi}

Mûsikî içinde türleri birbirinden ayırmak ve tanım yapmak için bazı terimleri ifade etmek gerekir. Sözlü mûsikî içinde "zemin" bölümü eserin takdimi niteliğindedir ve giriş bölümüdür. Çoğunlukla kullanılan 
makam bu bölümde özetlenir. "Nakarat" bölümü kompozisyon geliştirilir ve tekrar eden bölümdür. Eserin en tipik ve akılda kalıcı bölümü olduğu söylenebilir. "Meyan" bölümü genellikle makamın tiz bölgelerinde meydana getirilir. Ancak tizlerde dolaşılmayan eserler de mevcuttur. Bu bölümde bestekâr daha serbest kaldığı, farklı makamlara geçkilerin yapıldığı bölüm olduğu söylenebilir.

Büyük formda sözlü eserlerde (kâr, beste, ağır semai, yürük semai) güfteye dâhil olmayan anlamlı veya anlamsız sözlere "terennüm" adı verilmektedir. "İkâ̂-ritmik" ve "lafzî̀-sözlü" olmak üzere iki türlü terennüm kullanılmıştır. İkaî terennüm kendi başlarına bir anlam içermeyen, bir araya geldiğinde usül ile yakından ilgili bir gidiş gösteren terennümlere verilen addır. Mesela; "Ten nen", "Yel lel li”, "Tene na", "Tadir ney" gibi. Lâfzî terennüm ise kendi başına bir anlamı olan, bestekârın kendisinin güfteye eklediği terennümlerdir. Mesela "Hey cânım”, "A cânım”, "A sultânım” vb. veya başlı başına bir güfte de olabilir.

Özellikle şarkı formunun ortaya çıkıp popülerleşmesiyle birlikte beste ve semai türünde büyük formda eserlerin de git gide azaldığ 1 görülür. Şarkı formunu büyük formlu sözlü eserlerden ayıran en bâriz özellik terennümsüz oluşudur. Şarkı formunda yer alan nakarat ise büyük beste formlarında kullanılan terennümün karşılığı olduğunu söylemek yanlış olmayacaktır (Öztuna, 2000, s. 445).

Saz mûsikîsi içinde peşrev ve saz semailerinde her haneden sonra bestesi hiç değişmeyen, her haneyi birinci hanenin makamına döndürerek onda karar ettiren başlı başına bir "mülazime" olarak adlandırılmaktadır. Bir nevi sazlarla yapılan nakarat olarak da ifade edilebilir. XV. yüzyılda Merâği bunun için "serbend-hâne" veya "serbend-i pişrev" tabirini kullanmıştır (Bardakçı, 1986, s. 94). Ancak geçmişte mülazime olarak adlandırılan kısım bugün eserlerin yazılmış notalarına bakıldığında teslim olarak ifade edildiği görülmektedir. Halbuki teslim her hanenin sonunda o haneyi mülazimeye bağlayan (teslim eden) kısa ve değişmeyen ya da çok az değişebilen bir nağme veya nağme parçasıdır. Buna "terkib- i intikal" adı da verilir (Özkan, 2009, s. 220).

\section{Sonuç}

Pek çok alanda olduğu gibi Türk mûsikîsi formlarında da yenilikçi hareketlerle birlikte değişimler göze çarpmaktadır. Yeni türlerin ortaya çıkmasının yanı sıra bazı terimlerin de değişime uğradığı ve farklı adlarla kullanıldığı görülmektedir. Özellikle Osmanlı Devleti yüzünü Batı medeniyetine çevirmesiyle Batı'da kullanılmış olan bazı türlerin Türk mûsikîsi sahasına da girdiği tespit edilmiştir. Hacı Ârif Bey ile birlikte XIX. yüzyıldan itibaren şarkı formunun fasıllarda yer almaya başlamasıyla klasik büyük formların fasıllarda icrası azalmaya başlamış ancak her şeye rağmen büyük formlar az da olsa icradaki varlıklarını sürdürmüşlerdir. Ancak pek çok alanda olduğu gibi mûsikî de yozlaşmayla birlikte olumsuz yönde etkilenmiştir.

Geçmişten günümüze doğru sözlü mûsikî türlerinde olduğu gibi saz mûsikîsi türlerinde de kullanılan usullerin küçüldügü, daha küçük ve basit yapıda formların ortaya çıktığı görülmektedir. Meselâ peşrev formuna benzer medhal formu XIX. yüzyıldan sonra mûsikîmize girmiştir.

Yaptığımız çalışmada özellikle yenilikçi hareketlerle mûsikî türlerinin ne şekilde etkilendiğini ne tür değişiklikler olduğunu ortaya koymaya çalıştık. Günümüzde kullanılan mûsikî formlarının kurallarının yenilikçi dönem ile yazılmaya başlanmış ve klasik kurallar birleştirilerek yapılmıştır. Yazılan bu kuralların eserler incelendiğinde zaman zaman örtüşmediği de ortaya çıkmıştır.

Sonuç olarak yenilikçi hareketlerle başlayıp, XX. yüzyıl itibariyle popüler kültürün de etkisinin görülmesiyle günümüze kadar gelen süreçte Türk mûsikîsi formlarının epeyce değişkenlik gösterdiği, mûsikî formlarının ve terimlerinin bir kısmının değişime uğrayarak bugün kullanıldığı bir kısmının ise tamamen unutulduğu görülmektedir. Özellikle Türk mûsikîsi konusunda eğitim veren kurumların 
gelenekte kullanılan türleri doğru kaynaklardan inceleyerek günümüz türleri ile karşıllaştırmalı ve gelecek nesillere aktarılması hedeflenmelidir.

\section{Kaynakça}

Agayeva, S. (2007). Nevbet-i Müretteb. Türk diyanet vakfi İslâm ansiklopedisi içinde (Cilt 33). İstanbul: Türk Diyanet Vakfı Yayınları.

Akdoğu, O. (2005). Müziğin mi var derdin var. İzmir: Sade Matbaacılık.

Aksoy, B. (1994). Avrupalı gezginlerin gözüyle Osmanlılarda musiki. İstanbul: Pan Yayıncılık.

Aksoy, B. (1985). Tanzimat'tan Cumhuriyet'e musıki ve batılılaşma. Tanzimat'tan Cumhuriyet'e Türkiye Ansiklopedisi cilt 5 içinde. İstanbul: İletişim Yayınları.

Aktüze, İ. (2003). Müziği anlamak ansiklopedik müzik sözlüğü. İstanbul: Pan Yayınc1lık.

Akyıldız, A. (2011). Tanzimat. Türk diyanet vakfi İslâm ansiklopedisi içinde (Cilt 40). İstanbul: Türk Diyanet Vakfi Yayınları.

Alimdar, S. (2016). Osmanlı'da Batı müziği. İstanbul: Türkiye İş Bankası Yayınları.

Apel, W. (1981). Mazurka. Harvard dictionary of music second edition içinde. Cambridge Massachussets: The Belknap Press of Harvard University Press.

Bardakçı, M. (1986). Maragalı Abdülkadir. İstanbul: Pan Yayıncılık.

Cevher, M. H. (1995). Ali Ufki Bey ve Haza Mecmü'a-i Saz ü Söz (transkripsiyon, inceleme) (Doktora tezi). YÖk tez veri tabanından erişildi (Tez no: 42498).

Fonton, C. (1987). 18. yüzyılda Türk müziği. (C. Behar, Çev.). İstanbul: Pan Yayıncılık.

Kantemiroğlu, D. (2001). Kitabu İlmi'l-Mûsikî alâ vechi'l-Hurûfât. (Y. Tura, Çev.). İstanbul: Yap1 Kredi Yayınları.

Koç, F. (2010). Abdülaziz B. Abdülkâdir Merâğ̂̀ ve Nekâvetü'l-Edvâr isimli eserinin XV. yüzyll mûsikî nazariyatındaki yeri. (Doktora tezi). YÖK tez veri tabanından erişildi (Tez no: 273848).

Özalp, M. N. (1992). Türk mûsikîsi beste formları. Ankara: TRT Müzik Dairesi Yayınları.

Özcan, N. (2001). Türk mûsikîsi tarihi ders notları. Nuri Özcan'a ait 2001 yılı yayımlanmamış ders notları. İstanbul.

Özden, E. (2019). Osmanlı devleti'nin konservatuvarı arşiv belgeleriyle Dârülelhan. Ankara: AKM Yayınları.

Özkan, İ. H. (1984). Türk mûsikîsi nazariyatı ve usûlleri kudüm velveleleri. İstanbul: Ötüken Yayınları.

Özkan, İ. H. (1995). Fasıl. Türk diyanet vakfi İslâm ansiklopedisi içinde (Cilt 12). İstanbul: Türk Diyanet Vakf1 Yayınları.

Özkan, İ. H. (2001). Kâr. Türk diyanet vakfi İslâm ansiklopedisi içinde (Cilt 24). İstanbul: Türk Diyanet Vakfi Yayınları.

Özkan, İ. H. (2009). Saz Semaisi. Türk diyanet vakfı İslâm ansiklopedisi içinde (Cilt 36). İstanbul: Türk Diyanet Vakfi Yayınları.

Özkan, İ. H. (2010). Şark1. Türk diyanet vakfi İslâm ansiklopedisi içinde (Cilt 38). İstanbul: Türk Diyanet Vakfi Yayinları.

Öztuna, Y. (1969). Türk mûsikîsi tarihi ansiklopedisi (Cilt 1). Ankara: MEB Yayınları. 
Öztuna, Y. (2000). Türk mûsikîsi kavram ve terimler ansiklopedisi. Ankara: Atatürk Kültür Merkezi Yayınları.

Paçacı, G. (2010). Osmanlı Müziğini Okumak. İstanbul: T. C. Kültür Bakanlığı Yayınları.

Tanburî Cemil Bey Külliyatı. (2016). Çoban, Ninni [CD] içinde. İstanbul: Kalan Müzik

Tohumcu, A. (2007). Türk müziği terminolojisinde yozlaşma/örnek olay analizi: şark1 formu. II. Uluslararası Asya ve Kuzey Afrika Çalışmaları Kongresinde sunulan bildiri, Ankara.

Tura, Y. (1985). Türk mûsikîsi formları, eski formlar. Kaynaklar Dergisi, 4, 59-62.

Turabi, A. H. (1996). El-Kindî’nin mûsikî risâleleri (Yüksek lisans tezi). YÖK Tez veri tabanından erişildi (Tez no: 53667).

Uygun, N. (1999). Safiyyüddin Abdülmü'min Urmevî ve Kitabü'l-Edvârı. İstanbul: Kubbealtı Neşriyat.

Yavaş̧̧a, A. (2002). Türk mûsikîsi’nde kompozisyon ve beste biçimleri. İstanbul: Türk Kültürüne Hizmet Vakfı Yayınları. 